\title{
Men's Fertility in Second Unions in Three European Countries: The Effect of Parenthood Status
}

\author{
LIIVIA MURINKÓ and IVETT SZALMA
}

Hungarian Demographic Research Institute, Budapest, Hungary

Swiss Centre of Expertise in the Social Sciences, Lausanne, Switzerland

\begin{abstract}
In the present paper we investigate how fatherhood influences childbirth in the second union of men in three European countries. We use data from the first wave of the Generations and Gender Survey for France (2005), Norway (2007/8) and Hungary (2004/5) and we apply piecewise exponential event history models. The analysis complements earlier literature by focusing on men, taking a comparative perspective, looking at change over time, considering both cohabiting and marital unions, and also differentiating between the effects of non-residential and (part-or full-time) residential fatherhood.

Findings show that the probability of childbearing in the second union is the lowest if both partners already have child(ren) and highest if neither of them are parents. However we found different results if only one of the partners has pre-union children in the three countries. Findings are discussed in view of demographic trends, family and gender role attitudes, and relevant family policies.
\end{abstract}

Keywords: Male fertility, stepfamily, Generations and Gender Survey, France, Hungary, Norway

\section{Introduction}

There have been profound changes in partnership and fertility behaviour in the past decades all over Europe. Divorce rates have increased; unmarried cohabitation and outof-wedlock births have become more common in most European societies. The decline in union stability and the postponement of childbearing to higher ages have made it more difficult to attain the desired number of children in a single union, while the probability of birth in a subsequent union has increased. In this context multi-partnered fertility and stepfamilies offer a burgeoning area of research and help understand the implications of demographic changes for family life (Sweeney 2010).

On the country level, divorce and fertility rates are positively correlated in Europe (Billari and Kohler 2004); however, this relationship is not replicated on the individual level (Van Bavel, Jansen and Wijckmans. 2012). Partnership instability decreases fertility 
because the risk of childbirth is much lower for single than for partnered persons. . At the same time, union dissolutions produce a pool of persons who may enter subsequent partnerships and have additional children. Subsequent childbearing compensates for lost births to some degree (Beaujouan and Solaz 2008, 2013; Meggiolaro and Ongaro 2010; Thomson et al. 2012; Van Bavel et al. 2012).

Previous results on the relationship between repartnering and individual level fertility are mixed (e.g. Buber and Prskawetz 2000; Kalmijn and Gelissen 2007; Lappegård and Rønsen 2013; Meggiolaro and Ongaro 2010; Thomson and Li 2002; Vikat, Thomson and Hoem 1999). Mainly focusing on only one country, these studies do not consider the contextual factors which may lead to different outcomes in different countries (for exceptions: Henz and Thomson 2005; Thomson et al. 2014; Vikat, Thomson and Prskawetz 2004).

In order to capture structural effects we compare the impact of parenthood status on fertility in the second union of men in three European countries: Norway, France and Hungary, nations with different levels of public support for childrearing, custody law, gender equality and gender roles attitudes. We apply the same analytical design to each country, using the first wave of the Generations and Gender Survey (GGS). The analysis complements earlier literature by taking a comparative perspective, focusing on men, considering both cohabiting and marital unions, looking at change over time, and also differentiating between non-residential and part- or full-time residential fatherhood.

Most studies on fertility in second unions focus only on women and disregard men (for some exceptions: Beaujouan and Solaz 2013; Heintz-Martin, Le Bourdais and Hamplová 2014; Thomson and Li 2002). It is usually women who are the main caretakers, and data on female fertility is more readily available, more complete and accurate than on males (Beaujouan 2011; Breton and Prioux 2009; Meggiolaro and Ongaro 2010; Thomson et al. 2012). Moreover, it is mostly women who reside with the children after separation or divorce (de Graaf and Kalmijn 2003; Poortman 2007; Wu and Schimmele 2005).

In the present paper we focus on men for several reasons. Firstly, men's and fathers' involvement in family life and child care has been documented to increase in a number of societies, while women's growing participation in the labour market has strained traditional gendered division of family responsibilities (Cabrera et al. 2000; Williams 2008). Consequently, some researchers expect that fertility on the macro and micro level will be more influenced by men's behaviour and the level of gender equity (Goldscheider, Bernhardt and Brandén 2013; MacDonald 2013; O’Brien 2005). Additionally, many divorced or separated fathers do not live together with their children, with probably different effects on men's demographic behaviour after separation than on women's. And finally, biological constraints limit the fertility of men after a certain age less than in the case of women (Beaujouan 2011; Beaujouan and Solaz 2013; Van Bavel et al. 2012) - an aspect that is more important in the second union than in the first one -, thus leaving more space for other explanatory factors.

The following section describes relevant country differences, and then we provide 
a review of the main theoretical considerations and empirical studies on men's fertility within second unions. Subsequently, we present our hypotheses, we describe our data and methods, and finally we present and discuss our empirical findings.

\section{Overview of country background}

France, Norway and Hungary belong to different fertility regimes and significant differences can be found in their family policies, which may lead to different outcomes in post-separation fertility.

Total fertility rate was above 1.8 in France and Hungary and it was only 1.68 in Norway in 1985. During the 1990s fertility dropped sharply in Hungary while it only slightly decreased in France and even increased in Norway. After 2000 it further increased in Norway and France but kept decreasing in Hungary. As a result, fertility in France and Norway is among the highest in Europe, with 1.99 and 1.96 total fertility rates in 2008, respectively, and Hungary with its 1.35 total fertility rate belongs to the low fertility countries (OECD 2011a). Childlessness and non-marital births are somewhat less common in Hungary than in the other two countries (OECD 2011a).

In all of the three countries the institution of marriage has undergone significant changes, such as postponement to higher ages, decreasing marriage rates and increasing divorce rates (Spijker and Solsona 2012). In the 1980s total divorce rate was higher in Hungary (0.29) than in France (0.22) and Norway (0.24). Following a gradual increase, divorce rates were similar (0.45-0.47) in all of the three countries in 2007 and more than half of them involved children. Re-marriage rates of the divorced population have decreased since the 1980s, and around 25-30\% of divorced men re-married in the three countries in 2006 (Spijker and Solsona 2012). At the same time, more and more people choose to cohabit after a dissolved marriage, which compensates for declining remarriage rates to some extent.

After parental separation the child's residence is with the mother in most cases. The share of single-parent households that include the father and his child(ren) was higher in Norway (18\%) than in France (14.7\%) and Hungary (12.6\%) in 2010 (OECD 2011a). ${ }^{1}$ In 1980 it was around 14\% in France, $11 \%$ in Norway and 16\% in Hungary (UNECE 2016), thus the proportion of lone fathers compared to lone mothers has somewhat decreased in Hungary and it has increased in the two other countries.

The composition of lone fathers by marital status differs across countries. Around $40 \%$ of them are divorced and $20 \%$ are (still) married but living separately from their wives in all three countries (Eurostat 2011, authors' calculations). The share of widowed fathers living with their children is higher in Hungary (35\%) than in France (18\%) and

1 All dependent children who are younger than 25 years and live with only one parent are included in this calculation. 
Norway (10\%). Partly due to the different diffusion of unmarried unions, $26 \%$ of lone fathers are never married in the latter two countries but only $9 \%$ in Hungary.

The proportion of children placed in alternating residence is around $10 \%$ in Norway (4\% in 1996 and 10\% in 2004) and France (1\% in 1996 and 11\% in 2005) (BoeleWoelki, Braat and Curry-Sumner 2005; Council of Europe 2014) but negligible in Hungary (Weiss and Szeibert 2014). Alternating residence means that the children live substantially with both parents, although the actual practices of how the children divide their time between mother and father may vary. The share of parental and court decision on joint physical custody and the actual proportion of fathers and children in this arrangement are expected to increase.

Latest regulations in all three countries declare that both parents are regarded to be of equal importance for the child and decisions should be guided by the best interest of the child. No difference is made between married and non-married parents. While joint legal custody is regularly awarded, courts prefer joint physical custody arrangements only if all the necessary conditions are fulfilled and if parents are able to come to an agreement; however, still the majority of decisions place children in the full physical custody of the mother. Regulations that explicitly favour joint physical custody came into force in 2002 in France, in 2004 in Norway and only in March 2014 in Hungary (Council of Europe 2014).

In all three countries non-custodial parents have to contribute to the cost of raising a child by making child maintenance payments during the whole examined period. There are no different arrangements for children of married or unmarried parents. Contrary to the obligatory nature of the payments, there is considerable difference in the proportion of non-widowed single-parent families receiving child maintenance from the ex-partner: it was $81 \%$ in Norway, $46 \%$ in France and 40\% in Hungary in 2000 (OECD 2011a). The proportion of single parents receiving support payments has increased in most OECD countries since the 1990s, with the exceptions of France and Hungary (OECD 2011a). The share of child maintenance payment received as percentage of disposable income was $14 \%$ in France, $7 \%$ in Norway and 5\% in Hungary on average at the beginning of the new millennium (OECD 2011a).

In most countries the child support amounts are reduced or stopped when care is shared (equally) between resident and non-resident parents (OECD 2011b, 228). In the case of both shared and sole residential custody, having a subsequent partner and children are taken into account in France and only the new partner in Norway; however, these factors are often not considered in practice if the parents have relatively high earnings (Skinner, Bradshaw, and Davidson 2007). No such information is available for Hungary due to the marginality of shared parenting after separation. 


\section{Background and hypotheses}

Among other factors, childbearing decisions in a subsequent union are influenced by the previous fertility of the partners. Theoretically parenthood and commitment are the two main effects that are often discussed in the literature (Beaujouan 2011; Buber and Prskawetz 2000; Griffith, Koo and Suchindran 1985; Henz and Thomson 2005; Kalmijn and Gelissen 2007; Stewart 2002; Thomson and Li 2002).

Parenthood effect emphasises individual considerations (Griffith, Koo and Suchindran 1985; Kalmijn and Gelissen 2007). It supposes that people want to have a child because it renders them adult status. Accordingly, people who have not had children from their first relationship are more likely to have children in their second union than people who are already parents. It would mean that fertility does not depend on whether it is a first or a subsequent partnership.

Commitment effect concerns the couple level. It is based on the assumption that having shared children strengthens the union, so in a subsequent cohabitation or marriage the couple would like to have children in order to confirm their relationship. Consequently, fertility in subsequent unions does not depend on having pre-union children (Griffith et al. 1985; Vikat et al. 1999). According to a modified version of the commitment effect, the likelihood of childbirth is higher in a step-family than if all children were born in the same union (Beaujouan 2011; Buber and Prskawetz 2000).

Parental responsibility (Vikat et al. 2004) may modify the above-discussed effects of previous fertility. It emphasises that parenthood status matters for subsequent fertility only if the parents have parental responsibility (legal custody or physical custody) over the children. After divorce or separation parents may have sole or joint physical child custody and they may agree on different parenting schedules. Joint physical custody may mean that the child spends equal or a substantial amount of time with both parents, so it clearly implies that the child have ongoing close contact with both the mother and the father (Bauserman 2002).

Previous studies found mixed results regarding men's fertility in second unions. Evidence in favour of the commitment effect was first found by Griffith et al. (1985) for the United States, who confirmed that re-married women's prior number of children did not reduce their fertility in the subsequent marriage. Vikat et al. (1999) and Holland and Thomson (2011) for Sweden, Beaujouan (2011) for France, Thomson and Li (2002) and Stewart (2002) for the United States, and Heintz-Martin et al. (2014) for Canada also found evidence for the commitment effect in the case of men. Findings from Austrian data also support commitment effect if the partner has one pre-union child living in the household or only non-resident children (Buber and Prskawetz 2000). By contrast, some studies found a clearly negative association between childbearing and previous births on Dutch (Ivanova, Kalmijn and Unk 2014; Kalmijn and Gelissen 2007), British (Jefferies, Berrington and Diamond 2000) and Austrian data (Vikat et al. 2004). These results reinforce the parenthood effect.

The effect of parental responsibility was also established by studies which found 
different effects of previous biological children for men and women. Women's preunion children have stronger negative impact on childbearing than men's pre-union children do (Heintz-Martin et al. 2014; Kalmijn and Gelissen 2007; Stewart 2002; Stewart, Manning and Smock 2003; Thomson 1997; Thomson and Li 2002; Vikat et al. 2004) because women take greater responsibility in childrearing than men and men often withdraw from their non-residential children's lives, especially when they form a subsequent relationship (Guzzo and Furstenberg 2007; Manning and Smock 2000). Meanwhile some studies found that men's children have an equal or even stronger negative effect on continued childbearing than women's (Beaujouan 2011; Vikat et al. 1999). Comparing two countries with different social support to parents, Vikat and colleagues (2004) found that pre-union children are more likely to reduce the risk of birth in Austria than in Finland because the public support for childrearing and gender equality is lower in Austria than in Finland.

In the present paper we formulate four hypotheses for different configurations of parenthood status of the men and their female partners. We also take the country background into consideration. H1: Double parenthood hypothesis: We assume that if both partners have children from their previous union, they will be the least likely to have a shared child. We expect that this effect is the strongest in Hungary.

Justification: Having an additional child would not bring parenthood status for neither of the partners. Moreover, the total number of children of the couple is probably higher than if only one is a parent, which may also discourage further childbearing. In Hungary the material deprivation and income poverty of children and of households with children are considerably higher than in France and especially than in Norway (de Neubourg et al. 2012; OECD 2011a; UNICEF 2007).

H2: Childlessness hypothesis: We also expect that a couple has the highest chance to have common children if both the man and the woman are childless. We assume that this effect works in all three countries, and that the effect is the strongest in Hungary.

Justification: Parenthood and commitment effects strengthen each other in this case. Parenthood is considered the most important for Hungarian men and women and this consideration overrides the possible financial difficulties of childrearing, at least in the case of the first child. All international comparisons show that Hungarians are very family- and child-centred and they prefer traditional family models (Hobson and Fahlén 2009; Murinkó 2014; Oláh 2011; Saxonberg and Sirovatka 2006; Szalma 2010). ${ }^{2}$

H3: Childrearing support hypothesis: If the man is childless, we expect that the woman's pre-union children do not reduce the chances of childbirth in Norway and France but they do so in Hungary.

2 For example, $74 \%$ of Hungarians and $59 \%$ of the French agree with the statement that a man has to have children in order to be fulfilled, while less than $10 \%$ of the Norwegian respondents think the same (data from Generations and Gender Survey, 2004-2005 and 2007-2008, authors' calculations). 
Justification: French and Norwegian mothers can count on considerable help from the state, childcare institutions are widely available, and the fathers are more involved in childcare than in Hungary. In the French welfare system transfers to parents are generous and childcare is relatively well subsidised (Toulemon and de Guibert-Lantoine 1998). Norwegian family policy has gradually expanded from supporting only mothers' employment to emphasising also fathers' involvement in childcare. In spite of the fact that dual earner families are common in all of the three countries, the dual carer model is only widespread in Norway (Letablier 2013; Róbert, Bukodi and Luijkx 2001). At the same time Hungarian mothers can count on less help from the state and from the fathers of their children, and the reconciliation of family responsibilities and paid work is the most difficult there (Fodor et al. 2002; Szalma and Matysiak 2012; Saxonberg and Sirovatka 2006; Spéder 2011). Norway is one of the countries with the smallest difference between the two genders regarding reproductive health, empowerment and the labour market, while Hungary is among those countries where women are considerably less equal than men, and France is situated in between (Human Development Report 2014).

H4: Parental involvement hypothesis: We suppose that if only the man has pre-union children and his second partner is childless, this situation negatively affects childbearing in the second union only in Norway.

Justification: Norwegian men are relatively active in childrearing activities, even after separation (Craig 2005; Murinkó 2014). The level of gender equality is high and the Norwegian welfare state actively encourages fathers to participate in the lives of their children after parental separation or divorce (Skevik 2003, 2006), e.g. joint physical custody is more common in Norway and France than in Hungary (but it is still far from being the majority practice) (Council of Europe 2014). The relatively high child support payments of Norwegian fathers may also make them less likely to have additional children (OECD 2011b).

\section{Data and methods}

For the empirical analysis we use data from the first wave of the Generations and Gender Survey (GGS) for France (2005), Norway (2007-2008) and Hungary (2004-2005). The country surveys comprise of nationally representative samples of the population aged 18-79, focusing on family, fertility, partnerships, health, ageing and related attitudes. The data set includes complete fertility and partnership histories with monthly information. Individual weights adjust the distributions by gender, age and place of residence.

Our working sample includes men living in their second union (either marriage or cohabitation) that started in 1980 or later with a female partner who was aged between 18 and 40 at the beginning of the union. We use information on those second unions that were intact at the time of the survey. The risk period starts when the second coresident partnership starts, is censored at interview or when the partner becomes 45 . The event of interest is the first conception in the second union. The time of concep- 
tion is computed as the date of live birth minus nine months. The number of cases are summarised in Table 1.

Table 1. Number of cases

\begin{tabular}{l|l|l|l|l}
\hline & \multirow{2}{*}{$\begin{array}{l}\text { Total sample size } \\
\text { of GGS Wave 1 } \\
\text { (all respondents) }\end{array}$} & $\begin{array}{l}\text { persons (men living in } \\
\text { their second union) }\end{array}$ & $\begin{array}{c}\text { events (first conceptions } \\
\text { in men's second union) }\end{array}$ & $\begin{array}{l}\text { person- } \\
\text { months }\end{array}$ \\
\hline & & \multicolumn{3}{|c}{ in the working sample } \\
\hline France & 10079 & 421 & 257 & 23137 \\
Hungary & 13540 & 319 & 179 & 13595 \\
Norway & 14481 & 787 & 467 & 38874 \\
\hline
\end{tabular}

We model the hazard of the first conception in men's second unions with using piecewise exponential event history models with maximum likelihood estimation for each country separately. We assume a piecewise constant baseline hazard, where time since the beginning of the second union of men is partitioned into five phases: less than 1 year, $1-2$ years, $2-3$ years, $3-5$ years and 5 or more years.

Our main explanatory variable is the parenthood status of both the respondent and his female partner. The categories are the following: (1) neither of the partners have children, (2) only the man has children and all non-resident, (3) only the man has children and at least one is co-resident, (4) only the woman has children, (5) both have children and all children of the man are co-resident, and (6) both have children and at least one child of the man is co-resident. ${ }^{3}$ The parental status variable is dynamic in the sense that we keep track of the men's biological children leaving the household of the respondent. The differentiation between cases (time periods) when at least one child of the man is co-resident and cases when all of them live somewhere else is based on retrospective information on when the non-resident biological children of the respondent stopped living in the same household.

3 Several alternatives for the parenthood status variables have been tested. The simplest approach is to use a dummy variable (whether someone has any children or not), and there are several other possibilities that previous research has found to be useful predictors. We may make a distinction by the number of children, their residential status or age. The variables may either refer to the start of the risk period (time-constant) or they may be dynamic. Moreover, these criteria may be combined and in the case of the second analysis they may refer to both the respondent and his partner. We had to make a compromise between maximising information and minimising complexity. Different regression models (results not shown) indicate that the major distinctions are between having any children or not and whether any of the children live with the respondent. The female partners have hardly any non-resident children (or no information is available on them). The age of the children only marginally matters, and moreover, only few people with children above 18 are included in the two subsamples. 
It is important to note that in the analysis the co-residence of father and child means that the child lives with the father either full-time (sole physical custody) or part-time (joint physical custody). ${ }^{4}$ We use one single category for any type of co-residence between father and child mostly because the data set does not allow us to make further differentiation within this category and the number of cases would not make such a more detailed analysis possible. Moreover, shared physical custody is not the majority in any of the countries (Bjarnason and Arnarsson 2011). In spite of the fact that fathers might still spend less time with their children than mothers in the case of shared physical custody, children have better and more frequent relationship with their father and better outcomes in general if the parents share physical custody than if the children live with the mother (Bauserman 2002; Bjarnason and Arnarsson 2011; Nielsen 2011). We suppose that the major line of distinction is between fathers who have no physical custody and those who live with their children either on a part-time or full-time basis.

Other independent variables are period (calendar year) at the beginning of the union, time since the beginning of the partnership (dynamic variable), age of the respondent and his partner when their co-resident relationship started, and the educational background of both partners. Independent variables are summarised in Table 2. It is important to note that the number of cases/events is relatively low in the case of some variables, thus their hazard ratios should be treated with caution.

4 A child is co-resident with the respondent if he listed the child as a member if his household. According to the questionnaire manual, "[a] household consists of persons who live in the same dwelling-unit for at least four days in a normal week over a period of at least three months. In addition to them, there are dependent children with joint custody, and others who mainly live in the same dwelling-unit, but study or work at non-daily commuting distances or are temporarily in hospital, jail or military service. Visitors whose main place of residence is somewhere else do not belong to the household" (Vikat et al. 2005, 5). Thus if parents share physical child custody after separation both parents report that they live together with the child. Non-resident children include all biological or adopted children who are not listed as household members. 
Table 2. Exposure and occurrence table of the independent variables in the model for childbearing by country

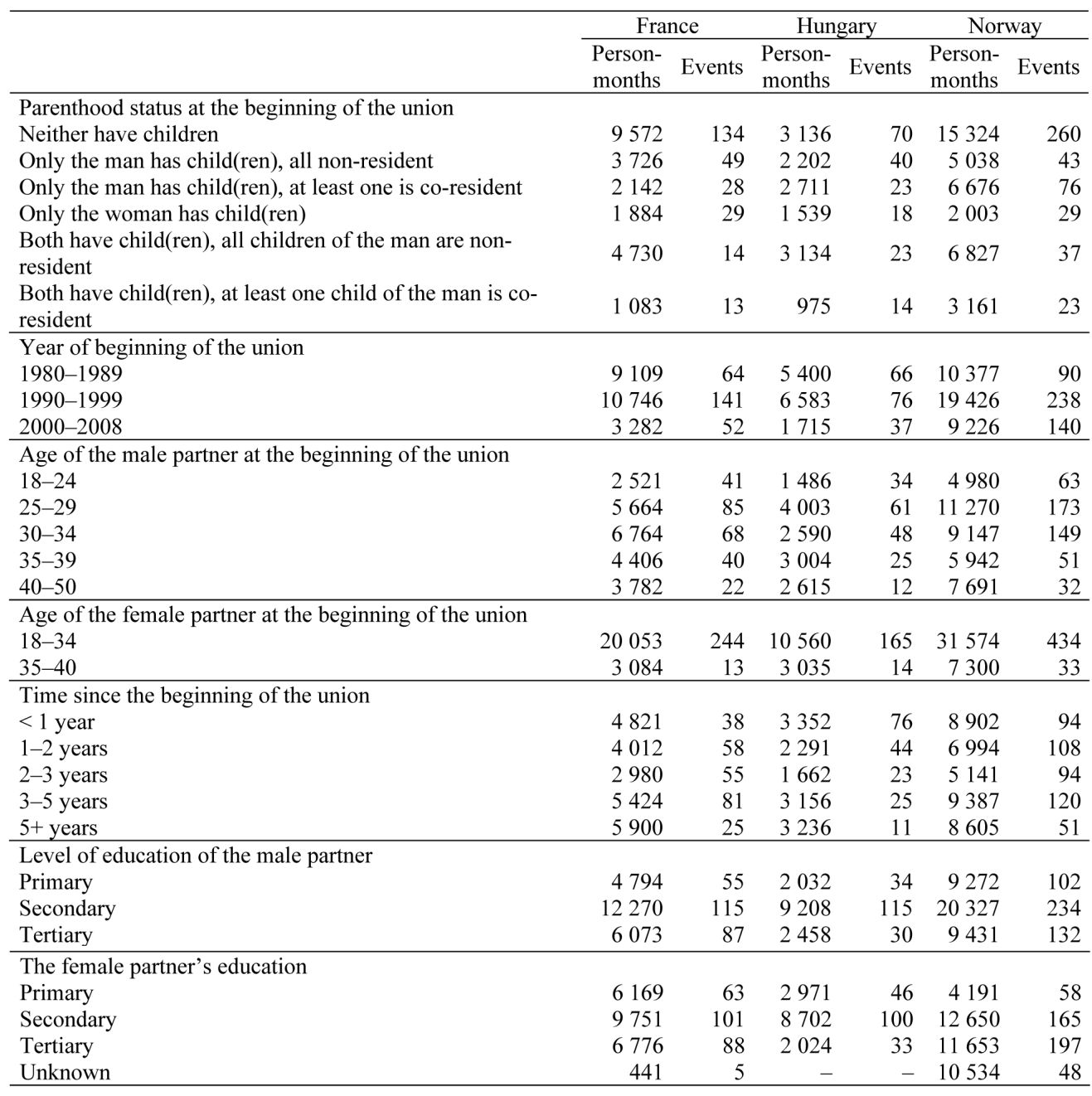

Our analytic approach and the data pose some limitations to the analysis. Firstly, women's non-resident children are probably somewhat under-reported in Hungary because no information is available on those non-resident children of the partner who have never lived with the respondent. Secondly, we consider shared physical custody and fathers' sole physical custody as the same category. Thirdly, we cannot look at people whose second union had already dissolved by the time of the data collection because the fertility history of past partners is not available. Consequently, second unions in the analysis probably belong to the "more successful" ones, which lasted long enough to be included. And fourthly, we have no information on a possibly important factor that men 
and women consider when they re-partner: fertility intentions. People who want (more) children, people who are satisfied with their current number of children or intentionally childless people may select a partner with complementary intentions.

\section{Findings}

In the empirical part of the paper we look at how parenthood status affects the fertility behaviour of men in their second cohabiting partnership or marriage.

The parenthood status of men and their partners differed at the beginning of the second union of men in the three examined countries (Table 3). While about half of the men were fathers at the beginning of their second union, most men chose childless women. This gender difference may result from the fact that mothers are less likely to re-partner than fathers (Beaujouan 2012; Ivanova et al. 2014; Lampard and Peggs 1999; Meggiolaro and Ongaro 2008; Wu and Schimmele 2005) and men usually choose younger women who are less likely to be already mothers. ${ }^{5}$ It was very uncommon that childless men partnered with mothers. In all three countries the most frequent combination was when both partners were childless.

Not only fatherhood but also the children's residence may matter for the childbearing choices of the new couple. The differentiation between fathers with only non-resident and with at least one part- or full-time co-resident child reveals further country differences (Table 3). 14\% of men in France, 20\% in Hungary and 24\% in Norway lived with their pre-union child(ren) either on a full- or part-time basis when they started their second union.

Table 3. The parenthood status of men and their partners at the beginning of the second union of men $(\%)$

\begin{tabular}{|c|c|c|c|c|}
\hline & & France & Hungary & Norway \\
\hline \multicolumn{2}{|l|}{ Neither have children } & 45.7 & 34.6 & 44.2 \\
\hline \multicolumn{2}{|c|}{ Only the woman has child(ren) } & 10.2 & 10.9 & 7.3 \\
\hline \multirow{2}{*}{$\begin{array}{l}\text { Only the man has } \\
\text { child(ren), ... }\end{array}$} & all non-resident & 15.9 & 19.7 & 9.0 \\
\hline & at least one is co-resident & 10.8 & 16.4 & 16.3 \\
\hline \multirow{2}{*}{$\begin{array}{l}\text { Both have child(ren), the } \\
\text { man has... }\end{array}$} & only non-resident & 14.1 & 14.5 & 15.6 \\
\hline & at least one co-resident & 3.3 & 3.9 & 7.6 \\
\hline \multicolumn{2}{|l|}{ Total } & 100.0 & 100.0 & 100.0 \\
\hline
\end{tabular}

5 In our working sample men are on average 3-4 years older than their cohabiting partners or wives. 
Until the end of the observation period, about every second couple had at least one common child in our sample. The probability of birth in the second union was $51 \%$ in Hungary, 54\% in Norway and 56\% in France. Regression results shed light on how fatherhood and motherhood status impacted the risk of childbirth in the second union of men (Table 4).

Table 4. Determinants of childbearing in the second union of men

\begin{tabular}{|c|c|c|c|c|c|c|}
\hline \multirow{2}{*}{ Parenthood status at the beginning of the union } & \multicolumn{2}{|c|}{ France } & \multicolumn{2}{|c|}{ Hungary } & \multicolumn{2}{|c|}{ Norway } \\
\hline & & & & & & \\
\hline Neither have children & (ref.) & & (ref.) & & (ref.) & \\
\hline Only the man has child(ren), all non-resident & 1.327 & & 0.876 & & 0.720 & $\dagger$ \\
\hline Only the man has child(ren), at least one is co-resident & 1.212 & & 0.557 & $*$ & 0.623 & $* *$ \\
\hline Only the woman has child(ren) & 1.209 & & 0.563 & $\dagger$ & 1.145 & \\
\hline Both have child(ren), all children of the man are non-resident & 0.352 & $*$ & 0.481 & * & 0.540 & $* *$ \\
\hline Both have child(ren), at least one child of the man is co-resident & 0.290 & $\dagger$ & 0.276 & $* *$ & 0.482 & $* *$ \\
\hline \multicolumn{7}{|l|}{ Year of beginning of the union } \\
\hline $1980-1989$ & (ref.) & & (ref.) & & (ref.) & \\
\hline $1990-1999$ & 1.334 & & 0.739 & $\dagger$ & 1.572 & $* * *$ \\
\hline $2000-2008$ & 1.609 & * & 0.815 & & 2.173 & $* * *$ \\
\hline \multicolumn{7}{|l|}{ Age of the male partner at the beginning of the union } \\
\hline $18-25$ & 1.149 & & 0.721 & & 0.623 & $* * *$ \\
\hline $25-30$ & 1.134 & & 0.803 & & 0.809 & $\dagger$ \\
\hline $30-35$ & (ref.) & & (ref.) & & (ref.) & \\
\hline $35-40$ & 0.917 & & 0.616 & $\dagger$ & 0.712 & \\
\hline $40-50$ & 0.695 & & 0.389 & $*$ & 0.434 & $* *$ \\
\hline \multicolumn{7}{|l|}{ Age of the female partner at the beginning of the union } \\
\hline $18-35$ & (ref.) & & (ref.) & & (ref.) & \\
\hline $35-40$ & 0.440 & $*$ & 0.346 & $* *$ & 0.441 & $* *$ \\
\hline \multicolumn{7}{|l|}{ Time since the beginning of the union (baseline hazard) } \\
\hline$<1$ year & 0.417 & $* * *$ & 1.281 & & 0.495 & $* * *$ \\
\hline $1-2$ years & 0.770 & & 1.253 & & 0.760 & $\dagger$ \\
\hline $2-3$ years & (ref.) & & (ref.) & & (ref.) & \\
\hline $3-5$ years & 0.905 & & 0.607 & & 0.793 & \\
\hline $5+$ years & 0.310 & $* * *$ & 0.235 & $* * *$ & 0.461 & $* * *$ \\
\hline \multicolumn{7}{|l|}{ The male partner's education } \\
\hline Primary & 1.024 & & 1.334 & & 1.045 & \\
\hline Secondary & (ref.) & & (ref.) & & (ref.) & \\
\hline Tertiary & 1.443 & * & 0.749 & & 1.030 & \\
\hline \multicolumn{7}{|l|}{ The female partner's education } \\
\hline Primary & 1.299 & & 1.307 & & 1.358 & $\dagger$ \\
\hline Secondary & (ref.) & & (ref.) & & (ref.) & \\
\hline Tertiary & 0.806 & & 1.540 & $*$ & 1.082 & \\
\hline Unknown & 0.847 & & - & & 0.282 & $* * *$ \\
\hline Intercept & 0.014 & $* * *$ & 0.037 & $* * *$ & 0.024 & $* * *$ \\
\hline Log likelihood & -480.3 & & -398.0 & & -875.8 & \\
\hline
\end{tabular}

Notes: piecewise exponential models, hazard ratios; significance: $* * * \mathrm{p}<0.001 * * \mathrm{p}<0.01 * \mathrm{p}<0.05 \dagger \mathrm{p}<0.1$ 
Regression results indicate that if both the man and his female partner are already parents, they are the least likely to have a common child in all three analysed countries (Table 4). This finding contradicts the commitment effect. Both partners already being parents have the strongest effect in France and Hungary and it hinders childbearing the least in Norway. The negative effect is somewhat stronger if at least one child of the man lives with them, either full-time or part-time (although differences by residence type are not statistically significant).

The lower rate of birth to couples where both are already parents compared to where only one has a child may have two explanations: either parenthood effect or the larger total number of children of the couple may influence their childbearing decision. In an alternative regression model we distinguished couples who have two children in total from those who have three or more children (but we could not differentiate children by their residence in these models due to the small number of cases; results are not shown). The risk of birth is the lowest if both partners are already parents. In France and Hungary there is no significant difference by the total number of children if both partners are already parents. However, in Norway couples with three or more children from their previous relationships are less likely to have a child together than couples with two children in total.

If the female partner is childless, being a father with only non-resident children makes childbearing less likely in Norway but not in Hungary or France. Motherhood seems to make no difference in France and Norway if the man is childless, while it reduces the risk of childbearing in Hungary. In Norway and France a new couple consisting of a childless men and a mother may want to and/or have the resources to show their commitment to each other by having a child together more often than in Hungary. A strong selection may be at work already during mate selection, since it is very uncommon in all the countries that childless men start their second union with mothers.

All the statistically significant effects for parenthood status are negative, meaning that childless men and women have the highest risk of having a common child. However, in some cases the lack of significant differences from the reference category indicates that there are other groups with similarly high risks. These groups include: French couples where only one of the partners have children, Hungarian men with only non-resident children who live with childless women, and childless men coupled with mothers in Norway.

Regarding the other independent variables, regression results show that the risk of childbearing in the second union of men has considerably increased since the 1980s in Norway and to a lesser extent in France. Hungary witnessed a decreased risk in the 1990s, in line with the sudden drop in overall fertility during this period. Thus the difference between the three examined countries in the probability of childbearing in the second union of men has increased since the 1980s.

The age of the partners also has an effect: childbearing is less likely if the man is over 40 or the woman is over 35 , and the young age of men also has a negative impact 
in Norway. Couples are the most likely to have their first shared child between one and five years after the beginning of their union. In France and Norway conception is less likely during the first year of the co-resident partnership. This is not the case in Hungary, where many couples move in together only after conception.

The education of the partners has a weak effect on childbearing in the second union of men; most hazard ratios are not significant. In France men with tertiary education, in Hungary highly educated women, and in Norway women with only primary education have a higher risk of childbearing than the other educational groups. In other words, the second-union fertility of men has no educational gradient in these three countries.

\section{Discussion and conclusions}

In the present paper we analysed how parenthood status affects childbearing in the second union of men in France, Norway and Hungary. We have formulated four hypotheses. The Double parenthood hypothesis (H1) has been confirmed. The probability of childbearing in the second union is the lowest if both partners already have at least one child. They may have fulfilled their fertility desires in their previous union and feel no need to have children together in the subsequent union. This effect applies to all the countries that we examined and it is the strongest in Hungary and France. The relative lack of financial problems (de Neubourg et al. 2012; OECD 2011a; UNICEF 2007), the presence of supportive family policies and high father involvement in child care (Craig 2005; Murinkó 2014; Skevik 2003, 2006) may explain that the negative effect is the weakest in Norway.

Results also confirmed the Childlessness hypothesis (H2): if both the man and the woman are childless, they are the most likely to have a common child in all three countries. The absolute risk of childbearing for childless couples is the highest in Hungary, indicating that the joint commitment and parenthood effects are the strongest in this country.

We found support for the Childrearing support hypothesis (H3), which concerned the effect of motherhood on fertility in the second union of men. Family and social policies, as well as the help of separated fathers make childbearing more likely in Norway and France than in Hungary for couples where the woman is already a parent but the man is not. The Parental involvement hypothesis (H4) has been partially confirmed. If only the man has pre-union children, it decreases the risk of childbirth in Norway, probably because of men's greater involvement in childcare and childrearing and the high level of gender equality. However, we also found a negative effect in Hungary for men with co-resident children who re-partnered with a childless woman.

All in all, commitment effect seems to prevail in France; parenthood effect works only if both partners are already parents, which is in accordance with the results of previous studies on France (Beaujouan 2011). It seems that having a common child is most important to stabilize a partnership in France or the French system of public sup- 
port makes it easier to achieve their relatively high ideal family size (OECD 2011a).

In Norway fatherhood negatively affects the risk of childbirth in a second union, regardless of where the children live or whether the female partner is already a mother or not. Apart from the fact that most men in Norway are probably relatively free from major financial difficulties, the changing attitudes towards partnerships and the increasingly turbulent partnership trajectories may explain this finding (Sobotka 2008).

We found that parenthood effect seems to prevail in Norway and Hungary. The exemptions are Hungarian fathers with only non-resident children and Norwegian mothers if the other partner is childless. On the one hand, separated Hungarian mothers bear the major responsibility of childrearing, shared custody is still uncommon. Consequently, fathers with non-resident children are relatively exempt from the responsibilities of caring for their children (even though they still have to pay child support) and they are the only group for which previous fertility does not impede continued childbearing. On the other hand, the greater involvement of Norwegian fathers also means that childcare is not the sole responsibility of separated mothers and their burden is lighter than in Hungary.

As we know from previous fertility studies, fertility is higher in those countries where the state is determined to help women reconcile work and family life (Del Boca 2002; Rindfuss et al. 2010). The present research shed light on the validity of this relationship among men who live in a second union. Additionally, fertility decisions are also influenced by the division of childcare between mothers and fathers. Fathers' higher participation in child care task can increase childbirth in the second union. Since fathers take part in childrearing more and more and female participation in the labour market has increased, the relationship between fathers' involvement in childcare and fertility should be examined in more detail. Our data does not allow us to examine this relationship at the individual level. We suggest that surveys should focus more on new family form such as shared child custody after separation and collect information about non-resident children in order to understand re-partnering and fertility in the growing number of higher order unions.

\section{Acknowledgements}

The research was partially supported by the project "Mapping Family Transitions: Causes, Consequences, Complexities, and Context" (no. K109397) of the Hungarian Scientific Research Fund (OTKA). The authors wish to thank Judit Takács and Tamás Bartus for their contribution to the first version of the paper.

\section{References}

Bauserman, R. (2002). Child adjustment in joint-custody versus sole-custody arrangements: a metaanalytic review. Journal of Family Psychology 16(1), 91-102.

Beaujouan, É. (2011). Second-union fertility in France: partners' age and other factors. Population-E 66(2), 239-74. 
- (2012). Repartnering in France: the role of gender, age and past fertility. Advances in Life Course Research 17(2), 69-80.

Beaujouan, É. \& Solaz, A. (2008). Childbearing after separation: do second unions make up for earlier missing births? Evidence from France. INED Working Papers 155.

- (2013). Racing against the biological clock? Childbearing and sterility among men and women in second unions in France. European Journal of Population 29(1), 39-67.

Billari, F. C., \& Kohler, H.-P. (2004). Patterns of low and lowest-low fertility in Europe. Population Studies 58(2), 161-76.

Bjarnason, T., \& Arnarsson, A. M. (2011). Joint physical custody and communication with parents: a cross-national study of children in 36 Western countries. Journal of Comparative Family Studies 42(6), 871-90.

Boele-Woelki, K., Braat, B., \& Curry-Sumner, I., Eds. (2005). European family law in action: parental responsibilities. Volume III. Antwerp/Oxford: Intersentia.

Breton, D., \& Prioux, F. (2009). The one-child family: France in the European context. Demographic Research 20(27), 657-92.

Buber, I., \& Prskawetz, A. (2000). Fertility in second unions in Austria: findings from the Austrian FFS. Demographic Research 3(2), 44.

Cabrera, N. J., Tamis-LeMonda, C. S., Bradley, R. H., Hofferth, S., \& Lamb, M. L. (2000). Fatherhood in the twenty-first century. Child Development 71(1), 127-36.

Council of Europe (2014). Council of Europe Family Policy Database. www.coe.int/familypolicy/ database [accessed 28 August 2014]

Craig, L. (2005). Cross-national comparison of the impact of children on adult time. SPRC Discussion Paper No. 137. Social Policy Research Centre, University of New South Wales.

de Graaf, P. M., \& Kalmijn, M. (2003). Alternative routes in the remarriage market: competing-risk analyses of union formation after divorce. Social Forces 81(4), 1459-98.

Del Boca, D. (2002). The effect of child care and part time opportunities on participation and fertility decisions in Italy. Journal of Population Economics 15(3), 549-573.

de Neubourg, C., Bradshaw, J., Chzhen, Y., Main, G., Martoano, B., \& Menchini, L. (2012). Child deprivation, multidimensional poverty and monetary poverty in Europe. Innoceti Working Paper No. 2012/02. Florence: UNICEF Innocenti Research Centre.

Eurostat (2011). The Census Hub: 2011 Census Database. Eurostat https://ec.europa.eu/CensusHub2/ [accessed 6 February 2016].

Fodor, E., Glass, C., Kawachi, J., \& Popescu, L. (2002). Family policies and gender in Hungary, Poland, and Romania. Communist and Post-Communist Studies 35(4), 475-90.

Goldscheider, F., Bernhardt, E., \& Brandén, M. (2013). Domestic gender equality and childbearing in Sweden. Demographic Research 29(40), 1097-126.

Griffith, J. D., Koo, H. P., \& Suchindran, C. M. (1985). Childbearing and family in re-marriage. Demography 22(1), 73-88.

Guzzo, K. B., \& Furstenberg, F. F. (2007). Multipartnered fertility among American men. Demography 44(3), 583-601.

Heintz-Martin, V., Le Bourdais, C., \& Hamplová, D. (2014). Childbearing among Canadian stepfamilies. Canadian Studies in Population 41(1/2), 61-77.

Henz, U., \& Thomson, E. (2005). Union stability and stepfamily fertility in Austria, Finland, France \& West Germany. European Journal of Population 21(1), 3-29.

Hobson, B., \& Fahlén, S. (2009). Competing scenarios for European fathers: applying Sen's capabilities and agency framework to work-family balance. The ANNALS of the American Academy of Political and Social Science 624(1), 214-33.

Holland, J. A., \& Thomson, E. (2011). Stepfamily childbearing in Sweden: quantum and tempo effects, 1950-99. Population Studies 65(1), 115-28. 
Human Development Report (2014). Human development report 2014. Sustaining human progress: reducing vulnerabilities and building resilience. New York: United Nations Development Programme.

Ivanova, K., Kalmijn, M., \& Unk, W. (2014). Fertility after repartnering in the Netherlands: parenthood or commitment? Advances in Life Course Research 21, 101-12.

Jefferies, J., Berrington, A., \& Diamond, I. (2000). Childbearing following marital dissolution in Britain. European Journal of Population 16(3), 193-210.

Kalmijn, M., \& Gelissen, J. (2007). The impact of recohabitation on fertility: evidence from life history data in the Netherlands. Journal of Comparative Family Studies 38(4), 555-573.

Lampard, R., \& Peggs, K. (1999). Repartnering: the relevance of parenthood and gender to cohabitation and remarriage among the formerly married. British Journal of Sociology 50(3), 443-65.

Lappegård, T., \& Rønsen, M. (2013). Socioeconomic differences in multipartner fertility among Norwegian men. Demography 50(3), 1135-53.

Letablier, M. (2013). The politics of parenting. In Ellingsaeter, A. L., Jensen, A. M., \& Lie, M. (Eds.) The social meaning of children and fertility change in Europe, pp. 12-30. London: Routledge.

MacDonald, P. (2013). Societal foundations for explaining fertility: gender equity. Demographic Research 28(34), 981-94.

Manning, W. D., \& Smock, P. J. (2000). “Swapping” families: serial parenting and economic support for children. Journal of Marriage and the Family 62(1), 111-22.

Meggiolaro, S., \& Ongaro, F. (2008). Repartnering after marital dissolution: does context play a role? Demographic Research 19(57), 1913-33.

- (2010). The implications of marital instability for a woman's fertility: empirical evidence from Italy. Demographic Research 23(34), 963-96.

Murinkó, L. (2014). A nemi szerepekkel és a családdal kapcsolatos attitüdök európai kitekintésben: Értékek és gyermekgondozás [Attitudes towards gender roles and family in a European perspective: Values and child care]. Szociológiai Szemle 24(1), 67-101.

Nielsen, L. (2011). Shared parenting after divorce: a review of shared residential parenting research. Journal of Divorce \& Remarriage 52(8), 586-609.

O'Brien, M. (2005). Shared caring: bringing fathers into the frame. Equal Opportunities Commission Working Paper Series No. 18. University of East Anglia.

OECD (2011a). OECD Family Database. Paris: OECD. www.oecd.org/social/family/database [accessed 17 September 2013].

— (2011b). Doing better for families. Paris: OECD. http://dx.doi.org/10.1787/9789264098732-en [accessed 8 December 2014].

Oláh, L. Sz. (2011). Should governments in Europe be more aggressive in pushing for gender equality to raise fertility? The second "YES". Demographic Research 24(9), 217-24.

Poortman, A. R. (2007). The first cut is the deepest? The role of the relationship career for union formation. European Sociological Review 23(5), 585-98.

Rindfuss, R. R., Guilkey, D. K., Morgan, S. P., \& Kravdal, Ø. (2010). Child-care availability and fertility in Norway. Population and Development Review 36(4), 725-48.

Róbert, P., Bukodi, E., \& Luijkx, R. (2001). Employment patterns in Hungarian couples. In Blossfeld, H-P., \& Drobnic, S. (Eds.) Careers of couples in contemporary society: from male breadwinner to dual-earner families, pp. 307-31. Oxford: Oxford University Press.

Saxonberg, S., \& Sirovatka, T. (2006). Failing family policy in post-communist Central Europe. Journal of Comparative Policy Analysis 8(2), 185-202.

Skevik, A. (2003). The new family's vulnerable vanguard: child maintenance reform in Norway. Social Policy \& Society 3(1), 11-9.

— (2006). 'Absent fathers' or 'reorganized families'? Variations in father $\square$ child contact after parental break $\square$ up in Norway. The Sociological Review 54(1), 114-32.

Skinner, C., Bradshaw, J., \& Davidson, J. (2007). Child support policy: an international perspective. Research Report No. 405. University of York, Department for Work and Pensions. 
Sobotka, T. (2008). Does persistent low fertility threaten the future of European populations? In Surkyn, J., Deboosere, P., \& van Bavel, J. (Eds.) Demographic challenges for the 21st century: a state of art in demography, pp. 27-89. Brusseles: Vubpress.

Spéder, Zs. (2011). Ellentmondó elvárások között... Családi férfiszerepek, apaképek a mai Magyarországon [Between contradicting expectations... Male roles in the family, image of fathers in contemporary Hungary]. In Nagy, I., \& Pongrácz, M. (Eds.) Szerepváltozások: jelentés a nök és férfiak helyzetéről 2011, pp. 207-28. Budapest: TÁRKI, Nemzeti Erőforrás Minisztérium.

Spijker, J., \& Solsona, M. (2012). Atlas of divorce and post-divorce indicators in Europe. Papers de Demografia 412. Centre d'Estudis Demogràfics, Universitat Autònoma de Barcelona.

Stewart, S. D. (2002). The effect of stepchildren on childbearing intentions and births. Demography 39(1), 181-97.

Stewart, S. D., Manning, W. D., \& Smock, P. J. (2003). Union formation among men in the U.S.: does having prior children matter? Journal of Marriage and Family 6(1), 90-104.

Sweeney, M. M. (2010). Remarriage and stepfamilies: strategic sites for family scholarship in the 21st century. Journal of Marriage and Family 72(3), 667-84.

Szalma, I. (2010). Attitüdök a házasságról és a gyermekvállalásról [Attitudes on marriage and childbearing]. Demográfia 53(1), 38-66.

Szalma, I., \& Matysiak, A. (2012). A nők munkaerő-piaci stratégiái és a második gyermekvállalás Lengyelországban és Magyarországon [Women's labour market strategies and the second birth in Poland and Hungary]. Demográfia 55(2/3), 172-95.

Thomson, E. (1997). Couple childbearing desires, intentions and births. Demography 34(3), 343-54.

Thomson, E., Lappegård, T., Carlson, M., Evans, A., \& Gray, E. (2014). Childbearing across partnerships in Australia, the United States, Norway, and Sweden. Demography 51(2), 485-508.

Thomson, E., \& Li, J. C. A. (2002). Her, his and their children: childbearing intentions and births in stepfamilies. NSFH Working Paper No. 89. Center for Demography and Ecology, University of Wisconsin-Madison.

Thomson, E., Winkler-Dworak, M., Spielauer, M., \& Prskawetz, A. (2012). Union instability as an engine of fertility? A microsimulation model for France. Demography 49(1), 175-95.

Toulemon, L., \& de Guibert-Lantoine, C. (1998). Fertility and Family Surveys in countries of the ECE region, standard country report France. Economic Studies No. 10e. New York \& Geneva: United Nations.

UNECE (2016). UNECE Statistical Database. New York \& Geneva: United Nations Economic Commission for Europe. www.unece.org/stats/data/ [accessed 6 February 2016].

UNICEF (2007). Child poverty in perspective: an overview of child well-being in rich countries. Innocenti Report Card 7. Florence: UNICEF Innocenti Research Centre.

Van Bavel, J., Jansen, M., \& Wijckmans, B. (2012). Has divorce become a pro-natal force in Europe at the turn of the 21st century? Population Research and Policy Review 31(5), 751-75.

Vikat, A., Beets, G., Billari, F., Bühler, C., Désesquelles, A., Fokkema, T., MacDonald, A. L., Neyer, G., Pailhé, A., Pinnelli, A., Solaz, A., \& Spéder, Zs. (2005). Wave I questionnaire manual. In United Nations Economic Commission for Europe, \& United Nations Population Fund (Eds.) Generations \& Gender Programme: survey instruments, pp. 15-32. New York \& Geneva: United Nations.

Vikat, A., Thomson, E., \& Hoem, J. M. (1999). Stepfamily fertility in contemporary Sweden: the impact of childbearing before the current union. Population Studies 53(2), 211-25.

Vikat, A., Thomson, E., \& Prskawetz, A. (2004). Childbearing responsibility and stepfamily fertility in Finland and Austria. European Journal of Population 20(1), 1-21.

Weiss, E., \& Szeibert, O. (2014). Parental Responsibilities - HUNGARY, national report. Utrecht: Commission on European Family Law. http://ceflonline.net/wp-content/uploads/Hungary-ParentalResponsibilities.pdf [accessed 30 May 2014].

Williams, S. (2008). What is fatherhood? Searching for a reflexive father. Sociology 42(3), 487-502. Wu, Z., \& Schimmele, C. M. (2005). Repartnering after first union disruption. Journal of Marriage and Family 67(1), 27-36. 